\title{
Growth and survival over ten years of Brazil-nut trees planted in three anthropogenic habitats in northern Amazonia
}

\author{
Ricardo SCOLES ${ }^{1 *}{ }^{\circledR}$, Rogério GRIBEL ${ }^{2}$ \\ 1 Universidade Federal do Oeste do Pará - UFOPA, Centro de Formação Interdisciplinar, Rua Vera Paz, s/n (Unidade Tapajós), Salé, CEP 68040-255 Santarém, Pará, \\ Brazil \\ 2 Instituto Nacional de Pesquisas da Amazônia - INPA, Coordenação de Biodiversidade, Av. André Araújo 2936, Petrópolis, CEP 69067-375 Manaus - AM, Brazil \\ * Corresponding author: ricardscoles@yahoo.es; (D) https://orcid.org/0000-0001-8483-6523
}

\begin{abstract}
We examined the growth and survival of Brazil-nut trees, Bertholletia excelsa (Lecythidaceae) under different environmental conditions and levels of canopy openness within experimental plantations in the Trombetas River valley, in northern Brazil. We planted 144 seedlings in three anthropogenic habitats with different levels of sunlight exposition: crop field (100\% canopy opening), shrub fallow (20-80\% canopy opening) and Brazil-nut forest ( $<10 \%$ canopy opening). We measured plant height and diameter annually and recorded mortality and resprouting over ten years. The performance of $B$. excelsa differed significantly among habitats, with the highest growth rate observed at the highest level of canopy openness (crop field). Survival was highest in crop field (85\%) and shrub fallow (63\%) and lowest in Brazil-nut forest (17\%). Resprouting capacity was higher in the crop field, as Brazil-nut plants recovered after fire episodes, with most plants resprouting more than one shoot. Some trees in the crop field began to produce flowers and fruits at 9-10 years. We showed that B. excelsa juveniles are light-demanding, with higher survival and growth under conditions of high light exposure. We suggest the use of Brazil-nut trees for reforestation, restoration of degraded lands and enrichment of secondary vegetation, as long as an adequate management is adopted (e.g., maintaining plants exposed to direct sunlight and control of competing pioneer species).
\end{abstract}

KEYWORDS: Bertholletia excelsa, plantation, light-demanding, land restoration, resprouting

\section{Crescimento e sobrevivência da castanheira do Brasil em três habitats antropogênicos após dez anos de plantação}

\section{RESUMO}

No presente estudo analisamos o crescimento e a sobrevivência da castanheira, Bertholletia excelsa (Lecythidaceae) em diferentes condiçóes ambientais e níveis de abertura de dossel em plantaçóes experimentais localizadas na bacia do Rio Trombetas, na Amazônia oriental brasileira. Plantamos 144 mudas em habitats antrópicos com diferentes intensidades de luz: roçados recentemente abandonados (100\% de abertura de dossel), capoeira de $2-3$ anos (20-80\% de abertura de dossel) e castanhal maduro ( $<10 \%$ de abertura de dossel). Anualmente, durante dez anos, medimos a altura e diâmetro das plantas, e registramos mortalidade e rebrotação. A performance de $B$. excelsa variou significativamente entre os habitats, tendo a taxa de crescimento mais alta sido observada no roçado. A sobrevivência foi mais alta no roçado (85\%) e na capoeira (63\%) e mais baixa no castanhal (17\%). A capacidade de rebrotação das plantas de castanheira foi maior no roçado, onde as plantas de castanheira se recuperaram após episódios de fogo, a maioria com rebrotação de mais de um caule. Algumas plantas do roçado começaram a produzir flores e frutos aos 9-10 anos do plantio. Nós mostramos que plantas jovens de $B$. excelsa são heliófilas (com alta demanda de luz), com maior crescimento e sobrevivência em condiçôes de alta luminosidade. Sugerimos a utilizaçấo da castanheira em programas de reflorestamento, restauração de áreas degradadas e enriquecimento de floresta secundária, sempre que se adotem medidas adequadas de manejo (e.g., manutenção das condiçóes de exposição direta à luz solar e controle de espécies pioneiras competidoras).

PALAVRAS-CHAVE: Bertholletia excelsa, plantação, espécie heliófila, recuperação de áreas degradadas, rebrotação

CITE AS: Scoles, R.; Gribel, R. 2021. Growth and survival over ten years of Brazil-nut trees planted in three anthropogenic habitats in northern Amazonia. Acta Amazonica 51: 20-29. 


\section{INTRODUCTION}

The Brazil-nut tree, Bertholletia excelsa Bonpl. (Lecythidaceae) is typical of the upland rain forests of the Amazonas and Orinoco river basins (Mori and Prance 1990; Peres et al. 2003). In forests, B. excelsa is a social species that tends to form aggregations, or stands, with 5-20 trees ha ${ }^{-1}$, known in Brazil as castanhais (Mori and Prance 1990). This Amazonian species is a large sized, dominant, emergent, longlived forest tree, and is light-dependent for juvenile growth (Mori and Prance 1990; Myers et al. 2000). For this reason, it is classified as a long-lived pioneer or a light-demanding climax species (Swaine and Whitmore 1988).

Bertholletia excelsa is considered a promising species for reforestation of degraded or deforested areas due to the high survival rate of planted seedlings ( $>70 \mathrm{~cm}$ tall), as well as its robustness, tolerance to degraded soils, resistance to prolonged droughts, excellent growth in high-light conditions and the onset of fruit production at about 8-10 years of age (Fernandes and Alencar 1993; Salomáo et al. 2006). The species has overall high survival under natural conditions, except during the initial life stages, when the hypocotyledon (a nutritional reserve structure of the seedling) is vulnerable to predation by herbivorous and frugivorous terrestrial mammals (Oliveira 2000; Zuidema and Boot 2002). Furthermore, B. excelsa has a high resprouting ability following disturbance events such as fire or physical damage (Balée and Campbell 1990; Paiva et al. 2011; Scoles et al. 2014).

The discontinuous distribution of the species in different regions of the Amazon, the difficulties in accessing its productive stands (Scoles and Gribel 2012) and the biological degradation of $B$. excelsa populations in urban and farming expansion areas (Homma et al. 2000; Scoles et al. 2016), justify the promotion of $B$. excelsa enrichment planting in areas close to human occupations. As a consequence of traditional itinerant agricultural practices, such as shifting cultivation and landscape management, anthropogenic ecosystems are predominant in these areas, generally in a state of secondary regeneration with medium or high exposure to sunlight.

The objective of this study was to evaluate the mediumterm (ten years) growth and survival of Brazil-nut tree seedlings planted under different ecological conditions mediated by canopy openness. Our study differs from other studies of B. excelsa experimental plantations (Kainer et al. 1998; Peña-Claros et al. 2002; Cotta et al. 2008; GarateQuispe et al., 2020) in that: (1) the tested light conditions were anthropogenic habitats resulting from usual activities of traditional Amazonian communities (crop field, shrub fallow and Brazil-nut forest (forest with B. excelsa stands), and, unlike Kainer et al. (1998), who tested similar conditions in the southeastern Amazon, we used a crop field instead of pasture; (2) there were no restrictions to the use of the experimental plantation areas by local people, to better simulate the real environmental conditions the seedlings were exposed to in anthropogenic environments; and (3) our experiment was monitored for a longer period (ten years) in comparison to other studies, which usually lasted for 4-5 years.

\section{MATERIAL AND METHODS}

\section{Study area}

The experimental plantations of Bertholletia excelsa were located in an area on the northwestern limit of the SaracáTaquera National Forest, a protected area in the Trombetas River basin, in the municipality of Oriximiná (state of Pará, Brazil) (Figure 1). The area is used by the inhabitants of the Tapagem village (1 $1^{\circ} 24^{\prime} 37.4^{\prime \prime} S$; 56 5 $\left.51^{\prime} 21.55^{\prime \prime W}\right)$, a community of quilombolas (i.e., Afro-Brazilian slave descendants) (Figure 1; Supplementary Material, Figure S1). The Trombetas River basin, especially in its upper and middle stretches, has large extensions of forests with abundance of Brazil nut stands, and many of these are located in areas that are either in protected public lands or legal property of quilombola communities (IBAMA 2004; Scoles and Gribel 2011, 2012).

The climate of the region is classified as Am in the Köppen system (Alvarez et al. 2013), tropical monsoon with driest

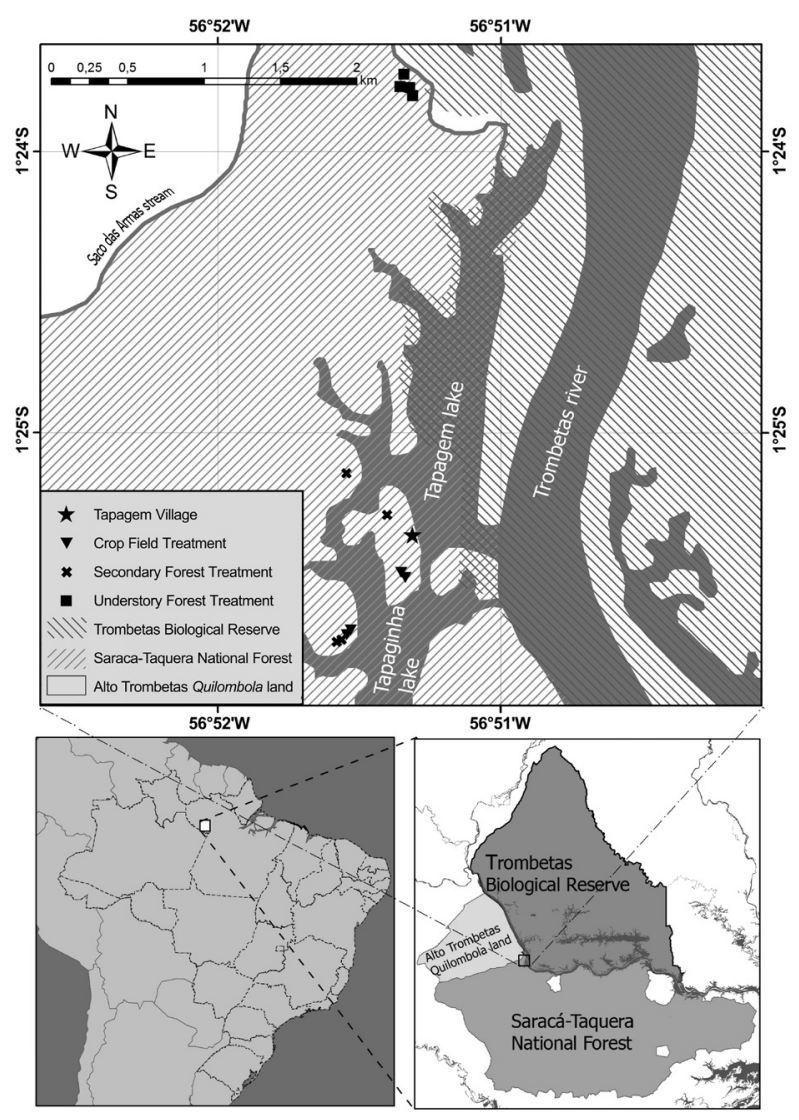

Figure 1. Location of the experimental plantation plots of Bertholletia excelsa in the National Forest of Saracá-Taquera in the Trombetas River basin, Oriximiná municipality, Pará state. Brazil. 
month $<60 \mathrm{~mm}$ precipitation. Mean annual temperatures is above $26^{\circ} \mathrm{C}$, annual precipitation ranges between 1,900 and $2,400 \mathrm{~mm}$, and mean relative humidity is of approximately $80 \%$. The rainfall peaks from March through May, and drier periods with monthly rainfall $<60 \mathrm{~mm}$ occur from August and September (Scoles and Gribel 2012; Alvarez et al. 2013). Data from an eleven-year series (2006-2016) from the meteorological station located nearest to the study area (Porto Trombetas, $1.47^{\circ} \mathrm{S}, 56.38^{\circ} \mathrm{W}$, approximately $54 \mathrm{~km}$ from the experimental plantations), registered an average annual precipitation of 2,010 $\pm 393 \mathrm{~mm}$, with a maximum in March $(375.0 \pm 104.1 \mathrm{~mm})$ and a minimum in August $(44.1 \pm 38.4 \mathrm{~mm})$. During this same period, average monthly humidity and temperature was $78.3 \pm 5.0 \%$ and $27.1 \pm 0.9$ ${ }^{\circ} \mathrm{C}$, respectively (Mineração do Rio Norte, unpublished data).

\section{Experimental design}

Brazil nut seedlings were planted in March 2007 in the vicinity of the Tapagem village. Three anthropogenic habitats with contrasting levels of seedling exposure to sunlight (canopy openness) were chosen for the experiment: (a) crop field: young fallow of manioc (Manihot esculenta) plantation 2-3 months after harvest, with nearly 100\% seedling direct exposure to sunlight; (b) shrub fallow: young secondary regrowth with 2-3 years of fallow, locally known as capoeira, with 20-80\% canopy openness; and (c) Brazil nut forest: anthropogenic forest stand dominated by trees of B. excelsa, locally known as castanhal, with high levels of shading $(<10 \%$ sunlight). The crop field and shrub fallow plots were inserted in a mosaic of anthropogenic habitats within shifting cultivation systems near Tapagem village, whereas the Brazil-nut forest plots were located in stands approximately $3 \mathrm{~km}$ from that village (Figure 1). Historical and ecological evidence that the forest stands dominated by $B$. excelsa in the Trombetas region are anthropogenic and managed by traditional populations were reported by Acevedo and Castro (1998) and Scoles and Gribel $(2011,2012)$.

We estimated canopy openness indirectly through the digital analysis of photographic images of the forest canopy (Engelbrecht and Herz 2001). One photograph was taken for each plant using a digital camera Ricoh GX100 with a wide-angular lens $(19 \mathrm{~mm})$, placed on a tripod $1.30 \mathrm{~m}$ above the ground, in conditions of indirect sunlight in the early morning. We processed the digital images using the Miramón 6.0 image analysis software. For each photograph, the software differentiates the package of white pixels (openings) of greyscale pixels (foliage) and calculates the proportion of white pixels out of the total number of pixels on a greyscale range of 0-256. The resulting percentage was transformed to the square root of the arcsine to normalize data distribution and was used as the measure of canopy openness.

In each anthropogenic habitat studied, four plots of approximately 0.3 ha were demarcated. Within each plot, 12 seedlings of $B$ excelsa were planted with $12 \times 12 \mathrm{~m}$ spacing. To maintain nearly $100 \%$ sunlight incidence on the $B$. excelsa seedlings in the crop field plots, we removed shading vegetation every six months throughout the experimental period. In the shrub fallow and Brazil-nut forest plots no management actions were taken, except for the removal of branches and vines that fell on the seedlings.

Given the small geographical scale of the experiment and the restrictions posed by the available anthropogenic habitats on the Tapagem landscape, the plots of each habitat were somewhat clustered (Figure 1). This study therefore suffered from spatial pseudo-replication which may cause artefactual results and consequently the findings should be viewed accordingly.

The geographic origin of the seeds for seedling production was diverse (states of Amapá, Rondônia and Pará) and this geographical diversity was equally distributed among the three habitats (for more details, see Scoles et al. 2011). The seedlings were planted with an average height of $107.6 \pm 15.8$ $\mathrm{cm}$ (varying from 80 to $120 \mathrm{~cm}$ ), and diameter of $7.9 \pm 2.1$ $\mathrm{mm}$, after 2 to 3 -year nursery cultivation. The planting hole was 40 x $40 \mathrm{~cm}$. We added organic fertilizers (cc. 500 gr.) to all planted seedlings.

Height, diameter and mortality were recorded annually from 2008 to 2017, as well as events of flowering/fruiting, seedling damage, and resprouting. Initially, the diameter was measured at the stem base, but, when the seedling reached 1.30 $\mathrm{m}$ in height, the DBH (diameter at breast height), which is measured at $1.3 \mathrm{~m}$ aboveground, was also measured. Damage to the plants occurred due to drying out from water stress, cuts and burning. The instruments used for measurements were: (a) tape meter and standardized measuring sticks for the height of stems, and (b) caliper or tape meter for the diameter of stems.

\section{Soil analysis}

Composite samples of soil were taken at the beginning of the study from 40-cm depth cores in each plot (twelve cores per plot). Physical (texture) and chemical ( $\mathrm{pH}$, carbon, cation exchange capacity - CEC, aluminum saturation and nutrients) analyses were conducted at the Plant and Soil Laboratory of Instituto Nacional de Pesquisas da Amazônia (INPA), in Manaus, state of Amazonas. The methods followed EMBRAPA (2017).

\section{Data analysis}

Survival was calculated as the proportion of surviving seedlings from one year to the next. Resprouting capacity was calculated as the ratio of the number of resprouted plants to the sum of resprouted and dead plants. Survival was analyzed for each habitat over the study period (ten years) using a Kaplan-Meier survival analysis (log-rank test) and resprouting was compared among habitats using a chi-square test $\left(\chi^{2}\right)$. 
The growth rate of the plants over the ten years was analyzed through the average annual increments in height $\left(\mathrm{AAI}_{\mathrm{h}}\right)$ and diameter $\left(\mathrm{AAI}_{\mathrm{d}}\right)$, using the average of the differences between the first and last measurements divided by the interval of ten years. We also compared the increments of growth among habitats per year. The growth of the plants

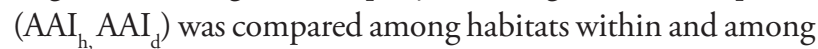
years using parametric ANOVA and the post hoc Tukey test, and the variables of physical and chemical soil properties were compared among habitats using the non-parametric Kruskal-Wallis test and the post hoc Dunn test. The significance level was adjusted with a Bonferroni correction for pairwise comparisons.

For plant-growth analysis, we used only live plants that did not suffer severe damage that affected their performance in the ten years of monitoring. Of the 144 planted individuals, 41 followed this criterion: 23 in crop-field, 17 in shrub fallow and only one in Brazil-nut forest. Data from plots within the same habitat were pooled since preliminary analyses found no significant difference among plots for any variable and because the low number of surviving plants in the Brazil-nut forest plots precluded statistical analysis based on four replications.

This research was authorized by Instituto Chico Mendes de Conservação da Biodiversidade (ICMBio) through SISBIO license \# 15234, and by the Coordination of the Tapagem quilombola community.

\section{RESULTS}

\section{Soil texture and chemical properties}

The soil texture was predominantly sandy in the crop-field (sand $=56.7 \pm 12.6 \%$; clay $=28.5 \pm 12.0 \%$; silt $=14.8 \pm$ $3.8 \%$ ) and shrub fallow (sand $=39.2 \pm 7.0 \%$; clay $=33.0 \pm$ $4.0 \%$; silt $=27.8 \pm 6.7 \%)$. In the Brazil-nut forest, the soil was slightly more clayey (sand $=32.8 \pm 6.1 \%$; clay $=42.0 \pm$ $10.6 \%$; silt, $25.2 \pm 9.4 \%)$. The differences among the habitats were not significant for the sand $(K=5.51, \mathrm{p}=0.064)$ clay $(\mathrm{K}$ $=3.23, \mathrm{p}=0.199)$ and silt $(\mathrm{K}=6.00, \mathrm{p}=0.05)$ fractions. In the silt fraction, the pairwise comparisons were not significant [Dunn test; all tests $>0.0167$ (Bonferroni's corrected level of significance)].

For most soil chemical variables $(\mathrm{pH}$, organic matter, CEC and nutrients), there was no significant difference among habitats, except for calcium and manganese concentrations in the Brazil-nut forest, which were significantly lower than those in the crop field and shrub fallow (Table 1). The base and aluminum saturations indicated a dystrophic soil in the Brazil-nut forest $(\mathrm{V} \%=23.0 ; \mathrm{m} \%=77.0)$, in contrast to the more eutrophic soils in the shrub fallow $(\mathrm{V} \%=59.0$;

Table 1. Comparison of soil variables among the three anthropogenic habitats in which the experimental plantations of Bertholletia excelsa were located in the National Forest of Saracá-Taquera, Oriximiná (Pará state, Brazil). Values are based on four plots per habitat and 12 samples per plot.

\begin{tabular}{|c|c|c|c|c|}
\hline Variable & Crop field & Shrub fallow & Brazil-nut forest & $p$ \\
\hline $\mathrm{pH}$ in $\mathrm{H}_{2} \mathrm{O}$ & $3.94 \pm 0.38$ & $4.08 \pm 0.32$ & $3.93 \pm 0.08$ & 0.664 \\
\hline Carbon $\left(\mathrm{mg} \mathrm{kg}^{-1}\right)$ & $11.74 \pm 3.72$ & $10.60 \pm 2.49$ & $13.91 \pm 2.33$ & 0.174 \\
\hline Nitrogen $\left(\mathrm{mg} \mathrm{kg}^{-1}\right)$ & $0.93 \pm 0.21$ & $0.90 \pm 0.21$ & $1.24 \pm 0.22$ & 0.138 \\
\hline $\mathrm{C} / \mathrm{N}$ & $12.42 \pm 1.38$ & $11.80 \pm 0.62$ & $11.24 \pm 1.16$ & 0.298 \\
\hline Organic matter (\%) & $2.02 \pm 0.64$ & $1.83 \pm 0.43$ & $2.40 \pm 0.40$ & 0.196 \\
\hline Phosphor (mg kg-1) & $14.60 \pm 6.98$ & $29.22 \pm 46.45$ & $12.42 \pm 2.15$ & 0.551 \\
\hline Calcium (mg kg-1) & $134.38 \pm 91.29^{a}$ & $133.00 \pm 61.11^{\mathrm{a}}$ & $27.38 \pm 10.56^{b}$ & 0.025 \\
\hline Magnesium (mg kg ${ }^{-1}$ ) & $29.88 \pm 24.83$ & $23.63 \pm 6.17$ & $19.88 \pm 3.68$ & 0.694 \\
\hline Potassium $\left(\mathrm{mg} \mathrm{kg}^{-1}\right)$ & $33.13 \pm 20.41$ & $27.00 \pm 6.92$ & $34.25 \pm 2.40$ & 0.232 \\
\hline Aluminum $\left(\mathrm{cmol}_{\mathrm{c}} \mathrm{kg}^{-1}\right)$ & $0.92 \pm 0.58$ & $0.68 \pm 0.34$ & $1.32 \pm 0.32$ & 0.138 \\
\hline $\operatorname{CEC}\left(\mathrm{cmol}_{\mathrm{c}} \mathrm{kg}^{-1}\right)$ & $1.93 \pm 0.97$ & $1.61 \pm 0.19$ & $1.71 \pm 0.38$ & 0.940 \\
\hline Bases saturation (V\%) & $53.17 \pm 21.92$ & $58.69 \pm 19.66$ & $22.95 \pm 3.52$ & 0.058 \\
\hline Aluminum saturation (m.\%) & $46.83 \pm 21.92$ & $41.31 \pm 19.66$ & $77.05 \pm 3.52$ & 0.058 \\
\hline Iron $\left(\mathrm{mg} \mathrm{kg}^{-1}\right)$ & $147.75 \pm 21.72$ & $117.00 \pm 42.15$ & $159.00 \pm 39.27$ & 0.491 \\
\hline Manganese $\left(\mathrm{mg} \mathrm{kg}^{-1}\right)$ & $10.15 \pm 6.99^{\mathrm{a}}$ & $15.08 \pm 7.04^{\mathrm{a}}$ & $1.55 \pm 0.39^{b}$ & 0.018 \\
\hline $\operatorname{Zinc}\left(\mathrm{mg} \mathrm{kg}^{-1}\right)$ & $0.63 \pm 0.30$ & $0.73 \pm 0.56$ & $0.93 \pm 0.34$ & 0.569 \\
\hline
\end{tabular}

Different upper-case letters in lines indicate significant differences according to the post hoc Dunn test. In lines with no upper-case letters, all comparisons were non-significant. $C / N=$ carbon/nitrogen ratio; $C E C=$ cation exchange capacity; $p=$ probability associated with the Krustal-Wallis test (significant at $p<0.00167$ after a Bonferroni correction). Table adapted from Scoles et al. (2011). 
$\mathrm{m} \%=41.3)$ and crop-field $(\mathrm{V} \%=53.3 \% ; \mathrm{m} \%=46.8)$. The differences in base saturation (V\%) among the habitats were non-significant $(p=0.058)$, suggesting a tendency for greater fertility and lower aluminum content in the shrub-fallow and crop-field soils compared to the Brazil-nut forest (Table 1).

\section{Survival}

The survival of plants after ten years of monitoring differed significantly among the habitats, with $85.4 \%$ in the crop-field, $62.5 \%$ in the shrub fallow, and $16.7 \%$ in the Brazil-nut forest. Survival was significantly lower in the Brazil-nut forest than in the other two habitats (log-rank test, $\left.\chi^{2}=6.026, \mathrm{p}<0.0001\right)$. Mortality in the Brazil-nut forest began to increase relative to the other plots in the third year (Figure 2), mostly due to broken and/or dried seedlings. Survival was significantly higher in the crop field than in the shrub fallow from the eighth year on (log-rank test, $8^{\text {th }}$ year, $\chi^{2}=4.703, p=0.03$; $9^{\text {th }}$ and $10^{\text {th }}, \chi^{2}=45.985, p=0.014$ ) (Figure 2). The effect of repeated occurrence of fire (two events) in two crop-field plots reduced the survival in this habitat to below $100 \%$ (see Resprouting).

\section{Resprouting}

After ten years, 38 plants had resprouted (48.1\% of live plants). Out of these, 18 were in crop field, 13 in shrub fallow and seven in Brazil-nut forest (43.9\%, 43.3\% and 87.5\% of live plants, respectively). Resprouting capacity at ten years varied among habitats. In the crop field, $72.0 \%$ of the seedlings that had been submitted to disturbance remained alive, as did $41.9 \%$ in the shrub fallow, and $14.9 \%$ in the Brazil-nut forest. These differences were significant among habitats $\left(\chi^{2}=27.286, \mathrm{p}<0.0001\right)$. In the crop-field plots and shrub-fallow plots, the damage that caused resprouting was primarily caused by human action (unintentional cutting and fire). Two plots in crop field were severely affected by fire between the second and third years, but only two seedlings

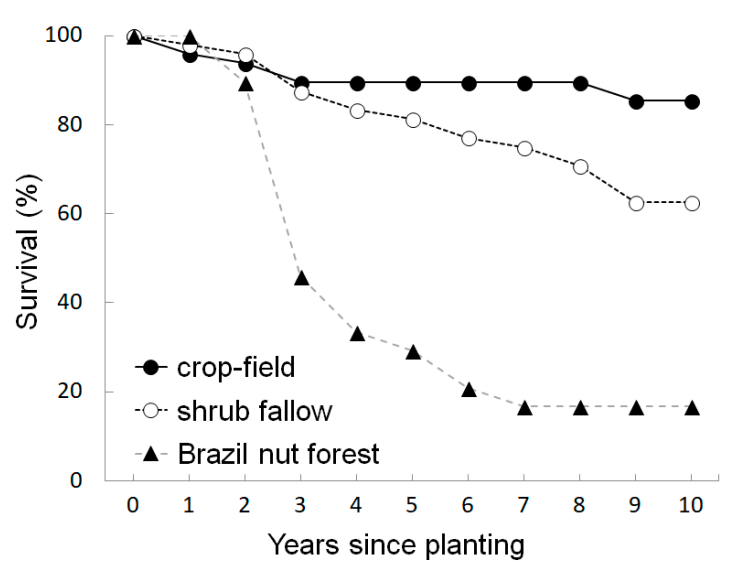

Figure 2. Yearly survival of Brazil-nut (Bertholletia excelsa) seedlings in experimental plantations under three different conditions of canopy openness in the National Forest of Saracá-Taquera, Oriximiná, Pará state, Brazil. died as a result of this disturbance. The vast majority $(90.5 \%$ of the plants) resprouted and grew vigorously at the start of the fourth year. The resprouting plants after fire disturbances formed more than one new stem (2-11 shoots; Supplementary Material, Figure S2).

\section{Growth}

The plants in crop field were higher and had thicker stems than those in the other habitats. The differences in height and diameter were highly significant between crop field and shrub fallow ( $\mathrm{p}<0.0001)$. Brazil-nut forest was not included in the analysis, as only one plant was alive at ten years (Figure 3).

$\mathrm{AAI}_{\mathrm{h}}$ was $150.3 \pm 27.0 \mathrm{~cm}$ year $^{-1}$ in crop field, which was six times higher than in shrub fallow $\left(\mathrm{AAI}_{\mathrm{h}}=25.0 \pm 15.9 \mathrm{~cm}\right.$ year $\left.^{-1}\right)$. Similarly, plant diameter grew nine times more quickly in crop field $\left(\mathrm{AAI}_{d}=1.9 \pm 0.4 \mathrm{~cm}\right.$ year $\left.{ }^{-1}\right)$ than in shrub fallow $\left(\mathrm{AAI}_{\mathrm{d}}=0.2 \pm 0.1 \mathrm{~cm}\right.$ year $\left.^{-1}\right)$. The sole surviving plant in Brazilnut forest had $\mathrm{AAI}_{\mathrm{h}}=27 \mathrm{~cm}$ year $^{-1}$ and $\mathrm{AAI}_{\mathrm{d}}=0.17 \mathrm{~cm}$ year $^{-1}$ (Supplementary Material, Figure S3), which was similar to the average growth rate in shrub fallow. In crov field. average
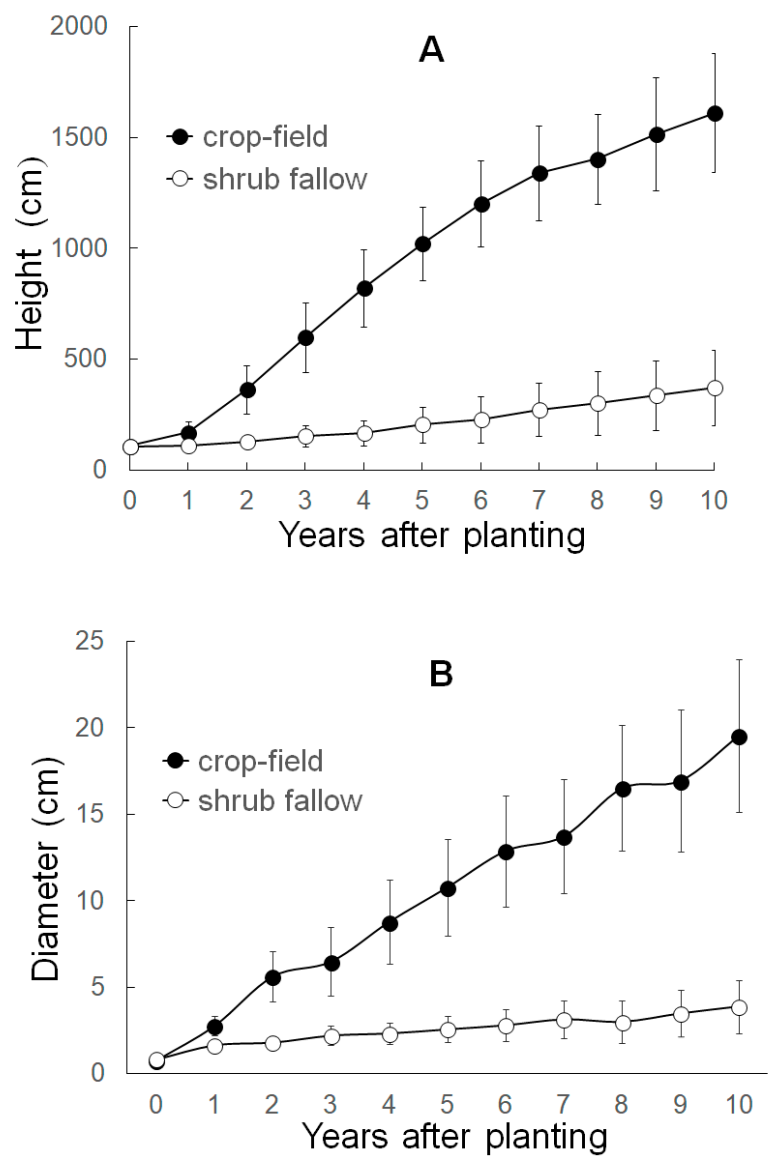

Figure 3. Average annual increment in height - $A A I_{b}(A)$ and diameter - AAl (B) of Bertholletia excelsa seedlings over ten years in experimental plantations in three anthropogenic habitats (crop fields, shrub fallow and Brazil-nut forest) in the National Forest of Saracá-Taquera, Oriximiná, Pará state, Brazil. Columns represent the mean and bars the standard deviation. 
height at ten years was $16.11 \pm 2.78 \mathrm{~m}$, and average diameter was $19.54 \pm 4.39 \mathrm{~cm}$ (Supplementary Material, Figure S4). Three plants in crop field produced flowers and fruits 9-10 years after being planted (Supplementary Material, Figure S5). In shrub fallow, average height at ten years was $3.72 \pm 1.72 \mathrm{~m}$, and average diameter was $3.87 \pm 1.55 \mathrm{~cm}$, which was more than five times lower than in the crop-field plots (Figure 4).

The yearly comparison of height and diameter of measurable plants alive at ten years (crop field, $n=23$; shrub fallow, $\mathrm{n}=17$ ) showed significantly higher values in both parameters for crop-field plants from the second year onwards (all tests $\mathrm{p}<0.0001$ ) (Figure 3).

\section{DISCUSSION}

\section{Survival}

The ten-year survival of the $B$. excelsa plants in the cropfield plots was higher than in shrub fallow, and much higher than in Brazil-nut forest, which contrasts with the high and similar survival in all three habitats during the first two years. Survival in our crop-field and shrub-fallow plots was higher than in other experimental studies of $B$. excelsa plantations
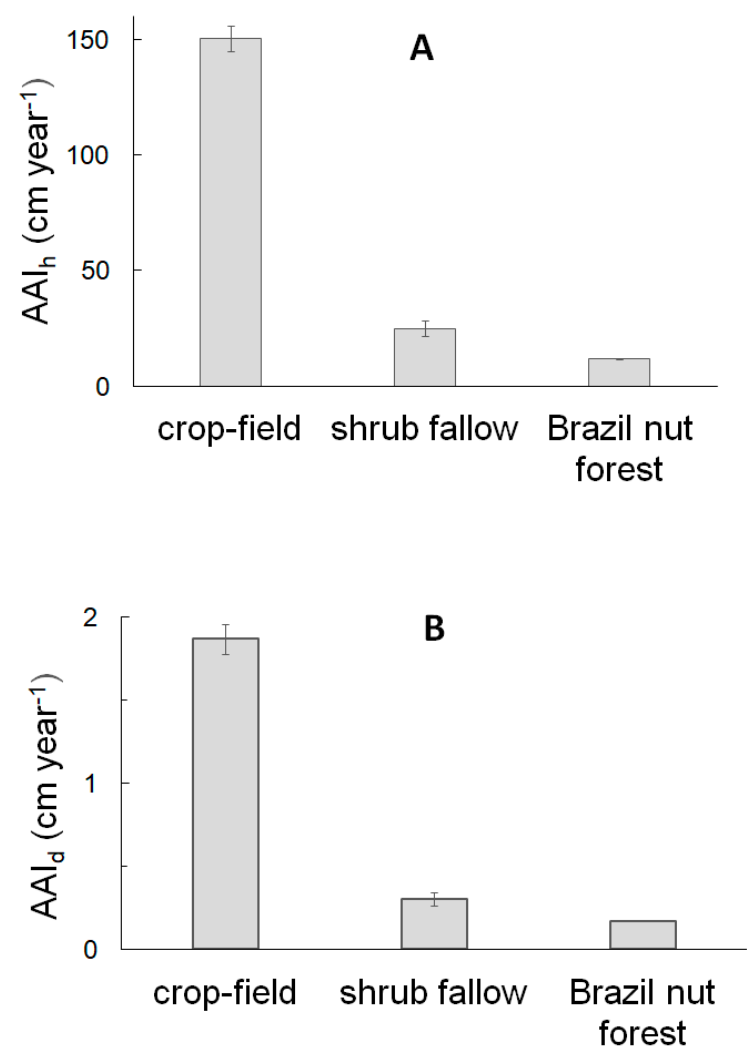

Figure 4. Overall average annual increment in height - $\mathrm{AAI}_{h}(\mathrm{~A})$ and diameter - $\mathrm{AAI}_{d}$ (B) of Bertholletia excelsa plants averaged over 10 years monitoring of experimental plantations in three anthropogenic habitats in the National Forest of Saracá-Taquera, Oriximiná, Pará state, Brazil. Columns represent the mean and bars the standard deviation. in pasture (Kainer et al. 1998) and timber-extraction sites (Oliveira 2000). The higher mortality in the latter studies was probably related to the use of much smaller seedlings (7-23 $\mathrm{cm})$ that are extremely vulnerable to attack by rodents due to the hypocotyledon in the stem base (Oliveira 2000; Zuidema e Boot 2002). In order to avoid predation, we planted taller seedlings $(80-120 \mathrm{~cm})$ without hypocotyledon reserve tissue, which previously showed to have higher survival probability in the field (Scoles et al. 2011).

The novelty of our study was the rapid decline in seedling and sapling survival in the Brazil-nut forest plots from the third year after planting, indicating that environments with a high level of shading reduce the growth and development of seedlings in the medium-term. In an experiment conducted in Bolivia, B. excelsa seedling survival after four years was also lower in high shade than in high light-intensity conditions (Peña-Claros et al. 2002). The significant differences in seedling survival rates among our experimental plantings in three habitats are consistent with results of field studies on $B$. excelsa regeneration. For example, Cotta et al. (2008) found significantly more saplings and seedlings in fallows than in nearby mature Brazil-nut forests in western Amazonia. Scoles and Gribel (2012) inventoried 25 plots of B. excelsa forests in the Trombetas Basin region and found less regenerants (seedlings, saplings, juveniles) in the more mature forest patches. An ongoing monitoring of the fate of $B$. excelsa seedlings in mature forests of the Trombetas region has shown that almost all (> 99\%) die after 8-10 years (R. Scoles and R. Gribel, unpublished data). The low rates of seedling recruitment in mature stands of $B$. excelsa were attributed to an excess of seed collection by local harvesters (Peres et al. 2003). In the Trombetas region, however, a detailed study on Brazil nut regeneration carried out in 25 Brazil-nut stands with different historical seed collection intensity found no evidence of such negative correlation between regeneration and harvest (Scoles and Gribel 2012). The conclusion of Peres et al. (2003) has not been confirmed by other studies (Wadt et al. 2008; Paiva et al. 2011; Ribeiro et al. 2014; Scoles and Gribel 2015), which have emphasized the role of unintentional seed dispersal by the harvesters during activities such as opening fruits, transporting and storing seeds. In addition, mild disturbances practiced by extractive populations in the forest structure, such as trails, understory clearings and selective logging, allow more light to reach the lower forest strata, which would facilitate the establishment of seedlings and juveniles of B. excelsa. Therefore, human extractive activities probably contribute to the rejuvenation of Brazil-nut stands and might counterbalance the negative effects of the recurrent, long-term removal of seeds from these forests.

\section{Resprouting after disturbances}

We demonstrated the high capacity for resprouting of B. excelsa after different types of disturbance, including fire. 
The temporal and environmental circumstances in this study allowed the observation of survival rate of plants after fire events, including vigorous resprouting, with the highest growth in height during the post-fire period (2010-2013) compared to the previous years (2007-2009). Our results indicate that B. excelsa plants are relatively tolerant to fire, which supports the notion that the species is an indicator of previous or recent anthropogenic disturbance (Balee and Campbell 1990; Scoles and Gribel 2011; 2015). The resprouting of more than one new stem was also commonly observed in B. excelsa populations near traditional communities in the Madeira River Basin (Scoles and Gribel 2015) and in protected areas of the state of Amapá (Guedes et al. 2014), including bi- and trifurcated stems. The resprouting in these studies possibly also resulted from disturbance by fire, since the $B$. excelsa individuals were located near human habitation or agricultural fields and areas with intense human transit.

\section{Plant growth, light exposure and edaphic conditions}

The higher incidence of sunlight on the crop fields is the most probable cause for the higher growth rate recorded in these plots in our study, as had already been recorded after two years (Scoles et al. 2011) and six years (Scoles et al. 2014) of monitoring of these experimental plantations. The characteristics of the soil in our plots (acidic, with low cation exchange capacity, low organic matter percentage, high concentration of iron and aluminum, and poor concentration of most analyzed nutrients) are typical of Amazonian nonflooded forests, which have low $\mathrm{pH}$, low fertility and CEC, high aluminum saturation, and are intensely weathered (Cochrane and Sánchez 1982; Schubart et al. 1984; Vieira and Santos 1987; Lopes and Guilherme 1992). Base saturation and nutrient values in our samples indicated that the soils in the Brazil-nut forest is dystrophic, while that in the shrub fallow and crop field is eutrophic. Lower soil fertility could possibly account for the lower growth and development of seedlings in the Brazil-nut forest, but soil fertility in the shrub fallow and crop field was similar and thus cannot explain the disparity in the growth and development of seedlings in these habitats. This suggests that greater height and diameter of plants in the crop field after ten years was mediated by higher sunlight incidence in this habitat.

Differences in growth and development of $B$. excelsa caused by differing sunlight-incidence levels have also been shown in other studies. In a four-year experimental plantation in secondary forests in Bolivia, Peña-Claros et al. (2002) observed that the establishment rate and growth in height of seedlings increased with the size of forest gaps. Furthermore, the growth rate of the seedlings planted in areas of shaded forest in Bolivia $\left(\mathrm{AAI}_{\mathrm{h}}=17 \mathrm{~cm}\right.$ year $\left.{ }^{-1}\right)$ was higher than in our study $\left(\mathrm{AAI}_{\mathrm{h}}=11.7 \pm 7.5 \mathrm{~cm}^{\mathrm{h}}\right.$ year $\left.^{-1}\right)$. In contrast, under conditions of full sunlight, the development of the seedlings in Bolivia was considerably lower $\left(\mathrm{AAI}_{\mathrm{h}}=96.5 \mathrm{~cm} \mathrm{year}^{-1}\right)$ than in our study in the first four years $\left(\mathrm{AAI}_{\mathrm{h}}=179.8 \mathrm{~cm} \mathrm{year}^{-1}\right)$ (Scoles et al. 2014). In an enrichment planting in a central Amazonian secondary forest, growth in height of $B$. excelsa was highest during the second year and responded positively to the exposure to light (Santos and Ferreira 2020). Similarly, in experimental plantings in tree-fall gaps and mature forest in the Peruvian Amazon, the annual increase in height and diameter of $B$. excelsa was significantly higher in gaps than in the understory forest (Garate-Quispe et al. 2020). In a study in the state of Acre, in the southwestern Brazilian Amazon, Kainer et al. (1998) compared the growth of B. excelsa seedlings during two years in pasture, secondary regrowth and forest gaps (71\%, 64\% and 21.5\% sunlight incidence, respectively) and observed that seedlings grew twice as much in the secondary regrowth than in pasture. As the incidence of sunlight was not significantly different between secondary regrowth and pasture, the higher growth in the secondary regrowth was probably due to greater soil compaction and lower nutrient content (calcium, potassium, magnesium, and extracted phosphorus) in the pasture areas.

The growth and developmentof $B$. excelsa plants in crop field in our study was similar to that registered in other experimental plantations monitored during similar periods (e.g., Fernandes and Alencar 1993; Tonini et al. 2005; Costa et al. 2009; Souza et al. 2008). The average growth rate in height in our crop-field plots $\left(\mathrm{AAI}_{\mathrm{h}}=1.5 \mathrm{~m}\right.$ year $\left.^{-1}\right)$ was similar to that recorded in other $B$. excelsa plantations, ranging between 1.3 and $2.0 \mathrm{~m}$ year $^{-1}$ (Scoles et al. 2014). Average diameter growth in our study $\left(\mathrm{AAI}_{\mathrm{d}}=2.1 \mathrm{~cm}\right.$ year $\left.^{-1}\right)$ was intermediate compared to other studies that reported rates of growth in diameter of less than $1.4 \mathrm{~cm}_{\text {year }}^{-1}$ to over $3 \mathrm{~cm}_{\text {year }}{ }^{-1}$ (Scoles et al. 2014). Our results from the current study are in agreement with those obtained in experimental plantations of B. excelsa (in monoculture or mixed-species culture) in open areas with no vegetation cover (Fernandes and Alencar 1993; Tonini et al. 2005; Costa et al. 2009; Souza et al. 2008), and confirm $B$. excelsa as a promising species for reforestation of degraded areas, on account of its high rate of survival, excellent growth in intense light conditions, and resistance to prolonged drought (Fernandes and Alencar 1993; Salomão et al. 2006; Costa et al. 2009; Souza et al. 2017, Schimpl et al. 2019). Furthermore, B. excelsa produces a large amount of dead organic matter in the form of leaves, thus promoting the cycling of nutrients in soils through litter production (Schroth et al. 2001; Silva et al. 2008; Costa et al. 2009). Required management practices would be to (a) select seedlings with height greater than $70 \mathrm{~cm}$; (b) produce seedlings from seeds collected from productive trees; (c) maintain juvenile plants exposed to direct sunlight, and (d) prevent competitive pioneer species from flourishing.

Conditions of intermediate incidence of sunlight appear to benefit the growth and development of $B$. excelsa plants after a certain period of time, since $\mathrm{AAI}_{\mathrm{h}}$ increased from 21.6 
$\mathrm{cm}$ year $^{-1}$ at six years after planting (Scoles et al. 2014) to 25 $\mathrm{cm}$ year $^{-1}$ at ten years (this study). Yet, compared to other studies (Kainer et al. 1998; Oliveira 2000; Peña-Claros et al. 2002) height growth rate in our shrub-fallow plots was lower $\left(\mathrm{AAI}_{\mathrm{h}}\right.$ between 57 and $96 \mathrm{~cm}_{\text {year }}{ }^{-1}$ ). In contrast, the diameter growth rate in our study $\left(\mathrm{AAI}_{\mathrm{d}}=0.20 \mathrm{~cm}_{\text {year }}{ }^{-1}\right.$ in ten years $)$ is similar to that observed in experimental forest-gap areas during five years $\left(\mathrm{AAI}_{d}=0.30 \mathrm{~cm}\right.$ year ${ }^{-1}$; Oliveira 2000), but lower than that in areas of secondary regrowth in an experimental plantation during two years $\left(\mathrm{AAI}_{\mathrm{d}}=0.7 \mathrm{~cm}_{\text {year }}{ }^{-1}\right.$; Kainer et al. 1998). The results for the intermediate light exposure in our experiment probably depended on specific local factors, such as competition with pioneer tree species for light and nutrients. In this context, it is important to emphasize that, in our experiment, the crop-field habitat was the only one where partial or total shading of the plants was actively prevented through regular cutting or pruning of competitor species.

The average growth in diameter of 21 stems from the Almeidas Plateau in the middle Trombetas River basin, estimated through the counting of growth rings, was $0.36 \mathrm{~cm}$ year ${ }^{-1}$, varying between 0.26 and $0.50 \mathrm{~cm}_{\text {year }}{ }^{-1}$ (Schöngart $e t$ al. 2015). These values are slightly higher than those found in our study for the $B$. excelsa trees planted in the shrubfallow plots, which suggests that the growth of the trees on the Almeidas Plateau may have occurred in a relatively open habitat. As the ages of the trees studied by Schöngart et al. (2015) varied approximately between 200 and 400 years, it is possible that the Almeidas Plateau, with 763 ha and 1,140 B. excelsa adults (as recorded by Salomão 2009), was an open area managed by Amerindians. These Brazil-nut stands of the middle Trombetas were abandoned by the Amerindians after the arrival of Europeans in the region, possibly due to depopulation caused by conflicts with European settlers, diseases, and migrations to the Trombetas headwaters and tributaries (Acevedo and Castro 1998; Scoles and Gribel 2011). From the beginning of the 19th century, fugitive slaves also ascended to the upper Trombetas region. Later, especially after the abolition of slavery in 1888 , they descended and established settlements in the middle stretch of the river, which already had reports of harboring vast Brazil-nut stands (Acevedo and Castro 1998).

\section{CONCLUSIONS}

The experimental plantations of Brazil nut (Bertholletia excelsa) under three different anthropogenic environmental conditions and a canopy openness gradient revealed significantly higher growth rates in height and diameter in open areas (crop-fields) than in areas of intermediate incidence of sunlight (shrub fallow) and high shading (Brazil-nut forest). Our data suggest that the main factor responsible for the high growth rates during the juvenile developmental phase was probably the exposure to direct sunlight. We also showed that the species has a great ability for resprouting after fire events, as long as high light-incidence conditions are maintained. Ten years after planting, seedling (> $80 \mathrm{~cm}$ tall) survival was high in the crop-field and shrub-fallow sites, whereas in the Brazil-nut forest sites, survival decreased significantly in the third year after planting, and the growth rate was extremely low. The Brazil-nut tree, which has a great socioeconomic and environmental importance in the Amazon basin, is further confirmed as a species with high potential for reforestation programs, recuperation of degraded lands, and enrichment of secondary vegetation, as long as an adequate management regime is adopted, in order to maintain juvenile plants exposed to direct sunlight and competitive pioneer species controlled.

\section{ACKNOWLEDGMENTS}

The authors thank the following institutions for project financing and logistical support for this research: Programa de Áreas Protegidas da Amazônia, Instituto Chico Mendes de Conservação da Biodiversidade (ICMBio), Conselho Nacional de Desenvolvimento Científico e Tecnológico - CNPq (process \# 426960/2016-5, beneficiary RS), Fundação Amazônica para Defesa da Biosfera, Instituto Internacional de Educação do Brasil, Banco de Germoplasma de Castanheira (Instituto Nacional de Pesquisas da Amazônia-INPA). CNPq provided a research grant to RS. We are also grateful to the INPA Plant and Soil Laboratory for the physical and chemical soil analyses, and officials of ICMBio, specially Gilmar Nicolau Klein, for technical and logistical support. Our most sincere gratitude to the families of the Tapagem quilombola community.

\section{REFERENCES}

Acevedo, R.E.; Castro, E. 1998. Negros do Trombetas: Guardiäs de Matas e Rios. 2nd ed. CEPUJ, Belém, Pará. 278p.

Alvarez, C.A.; Stape, J.L.; Sentelhas, P.C.; Gonçalves, J.L.M.; Sparovek, G. 2013. Köppen's climate classification map for Brazil. Meteorologische Zeitschrift, 22: 711-728.

Balée, W.; Campbell, D.G. 1990. Evidence of the successional status of liana forest (Xingú River Basin, Amazonian Brazil). Biotropica, 22: 36-47.

Cochrane, T.T.; Sánchez, P.A. 1982. Recursos de tierras, suelos y su manejo en la región amazónica: informe acerca del estado de conocimientos. In: Hecht, S.B. (Ed.). Amazonia. Investigación Sobre Agricultura y Usos de Sus Tierras. Centro Internacional de Agricultura Tropical, Cali, Colombia, p.169-185.

Costa, J.R.; Castro, A.B.C.; Wandelli, E.V.; Coral, S.C.T.; Souza, S.A.G. 2009. Aspectos silviculturais da castanha-do-brasil (Bertholletia excelsa) em sistemas agroflorestais na Amazônia Central. Acta Amazonica, 39: 843-850.

Cotta, J.N.; Kainer, K.A.; Wadt, L.H.O.; Staudhammer, C.L. 2008. Shifting cultivation effects on Brazil nut (Bertholletia excelsa) regeneration. Forest Ecology and Management, 256: 28-35. 
EMBRAPA. 2017. Manual de Análises Químicas de Solos, Plantas $e$ Fertilizantes. 3th ed. Empresa Brasileira de Pesquisas Agropecuárias - Embrapa Solos, Brasília, 574p.

Engelbrecht, B.M.J.; Herz, H.M. 2001. Evaluation of different methods to estimate understory light condictions in tropical forest. Journal of Tropical Ecology, 17: 207-224.

Fernandes, N.P.; Alencar, J.C. 1993. Desenvolvimento de árvores nativas em ensaios de espécies. 4. Castanha-do-Brasil (Bertholletia excelsa H. B. K.), dez anos após o plantio. Acta Amazonica, 23: 191-198.

Garate-Quispe, J.S.; Garcia Roca, M.R.; Alarcón Aguirre, G. 2020. Survival and growth of Brazil-nut seedlings in tree-fall gaps and forest understory. Floresta e Ambiente, 27: e20171168.

Guedes, M. C.; Neves, E. S.; Rodrigues, E. G.; Paiva, P.; Costa, J. B. P.; Freitas, M. F.; Lemos, L. M. 2014. 'Castanha na roça': expansão da produção e renovação dos castanhais em áreas de agricultura itinerante no Amapá, Brasil. Boletim Museu Paraense Emílio Goeldi. Ciências Naturais, 9: 381-398.

Homma, A.K.O.; Carvalho, R.A.; Ferreira, C.A.P.; Nascimento, J.D.N. 2000. A Destruição de Recursos Naturais: O Caso da Castanha-do-Pará no Sudeste Paraense. Doc. 32. Empresa Brasileira de Pesquisas Agropecuárias, Centro de Pesquisa Agropecuária do Trópico Úmido - Embrapa CPATU, Belém. $74 \mathrm{p}$.

IBAMA. 2004. Plano de Manejo da Reserva Biológica do Rio Trombetas, Instituto Brasileiro do Meio Ambiente e dos Recursos Naturais Renováveis, Brasília, 556p. (https://www. icmbio.gov.br/portal/unidadesdeconservacao/biomas-brasileiros/ amazonia/unidades-de-conservacao-amazonia/2003-rebio-dorio-trombetas). Accessed on 20 Jun 2020.

Lopes, A.S.; Guilherme, L.R.G. 1992. Interpretação e Análise do Solo: Conceitos e Aplicaçōes. 3rd ed. Associação Nacional para Difusão de Adubos, São Paulo, 50p.

Kainer, K.A.; Duryea, M.L.; Macedo, N.C.; Williams, K.1998. Brazil nut seedling establishment and autoecology in an extractive reserve in Acre, Brazil. Ecological Applications, 8: 397-410.

Mori, S.A.; Prance, G.T. 1990. Taxonomy, ecology, and economy botany of Brazil nut (Bertholletia excelsa Humb. e Bonpl.: Lecythidaceae). Advances in Economic Botany, 8: 130-150.

Myers, G.; Newton, A.C.; Melgarejo, O. 2000. The influence of canopy gap size on natural regeneration of Brazil nut (Bertholletia excelsa) in Bolivia. Forest Ecology and Management, 127: 119-128.

Oliveira, M.V.T. 2000. Artificial regeneration in gaps and skidding trails after mechanized forest exploitation in Acre, Brazil. Forest Ecology and Management, 127: 67-76.

Paiva, P.M.; Guedes, M.C.; Funi, C. 2011. Brazil nut conservation through shifting cultivation. Forest Ecology and Management, 261: 508-514.

Peña-Claros, M.; Boot, R.G.A.; Dorado-Lora, J; Zonta, A. 2002. Enrichment planting of Bertholletia excelsa in secondary forest in the Bolivian Amazon: effect of cutting line width on survival, growth and crown traits. Forest Ecology and Management, 161: 159-168.
Peres, C.A.; Baider, C.; Zuidema, P.A.; Wadt, L.H.O.; Kainer, K.A.; Gomes-Silva, D.A.P.; et al. 2003. Demographic threat to the sustainability of Brazil nut exploitation. Science, 302: 2112-2114.

Ribeiro, M.B.N.; Jerozolimski, A.; de Robert, P.; Salles, N.V.; Kayapó, B.; Pimentel, T.P.; Magnusson, W.E. 2014. Anthropogenic landscape in southeastern Amazonia: contemporary impacts of low-intensity harvesting and dispersal of Brazil nuts by the Kayapó Indigenous people. PLoS ONE, 9: e102187.

Salomão, R.P. 2009. Densidade, estrutura e distribuição espacial de castanheira-do-brasil (Bertholletia excelsa H. e B.) em dois platôs de floresta ombrófila densa na Amazônia setentrional brasileira. Boletim do Museu Paraense Emilio Goeldi, Ciências Naturais, 4: 11-25.

Salomão, R.P.; Rosa, N.A.; Castilho, A.; Morais, A. 2006. Castanheira-do-Brasil recuperando áreas degradadas e provendo alimento e renda para comunidades de Amazônia Setentrional. Boletim do Museu Paraense Emilio Goeldi. Ciências Naturais, 2: 65-78.

Santos, V.A.H.F.; Ferreira, M.J. 2020. Initial establishment of commercial tree species under enrichment planting in a Central Amazon secondary forest: Effects of silvicultural treatments. Forest Ecology and Management, 460: 117822.

Schimpl, F.C.; Ferreira, M.J.; Jaquetti, R.K.; Martins, S.C.V.; Gonçalves, J.F.C. 2019. Physiological responses of young Brazil nut (Bertholletia excelsa) plants to drought stress and subsequent rewatering. Flora, 252: 10-17.

Schöngart, J.; Gribel, R.; Fonseca, S.F.J.; Haugaasen, T. 2015. Age and growth patterns of Brazil nut trees (Bertholletia excelsa Bonpl) in Amazonia, Brazil. Biotropica 4 47: 550-558.

Schroth, G.; Lehmann, J.; Rodrigues, M.R.L.; Barros, B.; Macêdo, J.L.V. 2001. Plant-soil interactions in multistrata agroforestry in the humid tropics. Agroforestry Systems, 53: 85-102.

Schubart, H.O.R.; Franken, W.; Luizão, F.J. 1984. Uma floresta sobre solos pobres. Ciência Hoje, 2: 26-32.

Scoles, R.; Canto, M.S.; Almeida, G.R.; Vieira, D.P. 2016. Sobrevivência e frutificação de Bertholletia excelsa Bonpl. em áreas desmatadas em Oriximiná, Pará. Floresta e Ambiente, 23: 555-564.

Scoles, R.; Gribel, R. 2011. Population structure of Brazil nut (Bertholletia excelsa, Lecythidaceae) stands in two areas with different occupation histories in the Brazilian Amazon. Human Ecology, 39: 455-464.

Scoles, R.; Gribel, R. 2012. The regeneration of Brazil nut trees in relation to nut harvest intensity in the Trombetas River valley of northern Amazonia, Brazil. Forest Ecology and Management, 265: 71-81.

Scoles, R.; Gribel, R. 2015. Human influence on the regeneration of Brazil nut tree (Bertholletia excelsa, Lecythidaceae) at the Capanã Grande Lake, Manicoré, Amazonas, Brazil. Human Ecology, 43: 843-854.

Scoles, R.; Klein, G.N.; Gribel, R. 2011. Crescimento e sobrevivência de Bertholletia excelsa Bonpl. (castanheira) em diferentes condições ambientais na região do rio Trombetas, Oriximiná, Pará. Boletim Museu Paraense Emílio Goeldi. Ciências Naturais, 6: 273-293. 
Scoles, R.; Klein, G.N.; Gribel, R. 2014. Crescimento e sobrevivência de castanheira (Bertholletia excelsa Bonpl; Lecythidaceae) plantada em diferentes condiçôes de luminosidade após seis anos de plantio na região do Rio Trombetas, Oriximiná, Pará. Boletim Museu Emilio Goeldi, Ciências Naturais, 9: 321-336.

Silva, P.T.E.; Brienza; J.R.S.; Yared, J.A.G.; Barros, P.L.C.; Maciel, M.N.M. 2008. Principais espécies florestais utilizadas em sistemas agroflorestais na Amazônia. Revista de Ciências Agrárias, 49: 127-144.

Souza, C.R.R.; Lima, M.B.; Azevedo, C.P.E.; Rossi, L.M.B. 2008. Desempenho de espécies florestais de uso múltiplo. Scientia Forestalis, 36: 7-14.

Souza, C.S.C.R.; Santos, V.A.H.F.; Ferreira, M.J.; Gonçalves, J.F.C. 2017. Biomassa, crescimento e respostas ecofisiológicas de plantas jovens de Bertholletia excelsa Bonpl. submetidas a diferentes níveis de irradiância. Ciência Florestal, 27: 557-569.

Swaine, M.D.; Whitmore, T.C. 1988. On the definition of ecological species groups in tropical rain forests. Vegetatio, 75: 81-86.

Tonini, H.; Arco-Verde, M.F.; Sa, S.P.P. 2005. Dendrometria de espécies nativas em plantios homogêneos no estado de
Roraima: andiroba (Carapa guianensis Aubl), castanha-do-brasil (Bertholletia excelsa Bonpl.), ipê-roxo (Tabebuia avellanedae Lorentz ex Griseb) e jatobá (Hymenaea courbaril L.). Acta Amazonica, 35: 353-362.

Vieira, L.S.; Santos, P.C.T.C. 1987. Amazônia, seus solos e outros recursos naturais. Agronômica Ceres, São Paulo. 416p.

Wadt, L.H.O.; Kainer, K.A.; Staudhammer, C.L.; Serrano, R.O.P. 2008. Sustainable forest use in Brazilian extractive reserves: Natural regeneration of Brazil nut in exploited populations. Biological Conservation, 141: 332-346.

Zuidema, P.A.; Boot, R.G.A. 2002. Demography of the Brazil nut tree (Bertholletia excelsa) in the Bolivian Amazon: impact of seed extraction on recruitment and population dynamics. Journal of Tropical Ecology, 18: 1-31.

RECEIVED: $24 / 04 / 2020$

ACCEPTED: 04/01/2021

ASSOCIATE EDITOR: Carolina V. Castilho 
ACTA

AMAZONICA

SCOLES \& GRIBEL. Ten-year growth and survival of Brazil-nut trees

SUPPLEMENTARY MATERIAL (only available in the electronic version)

Scoles \& Gribel. Growth and survival over ten years of Brazil-nut trees planted in three anthropogenic habitats in northern Amazonia

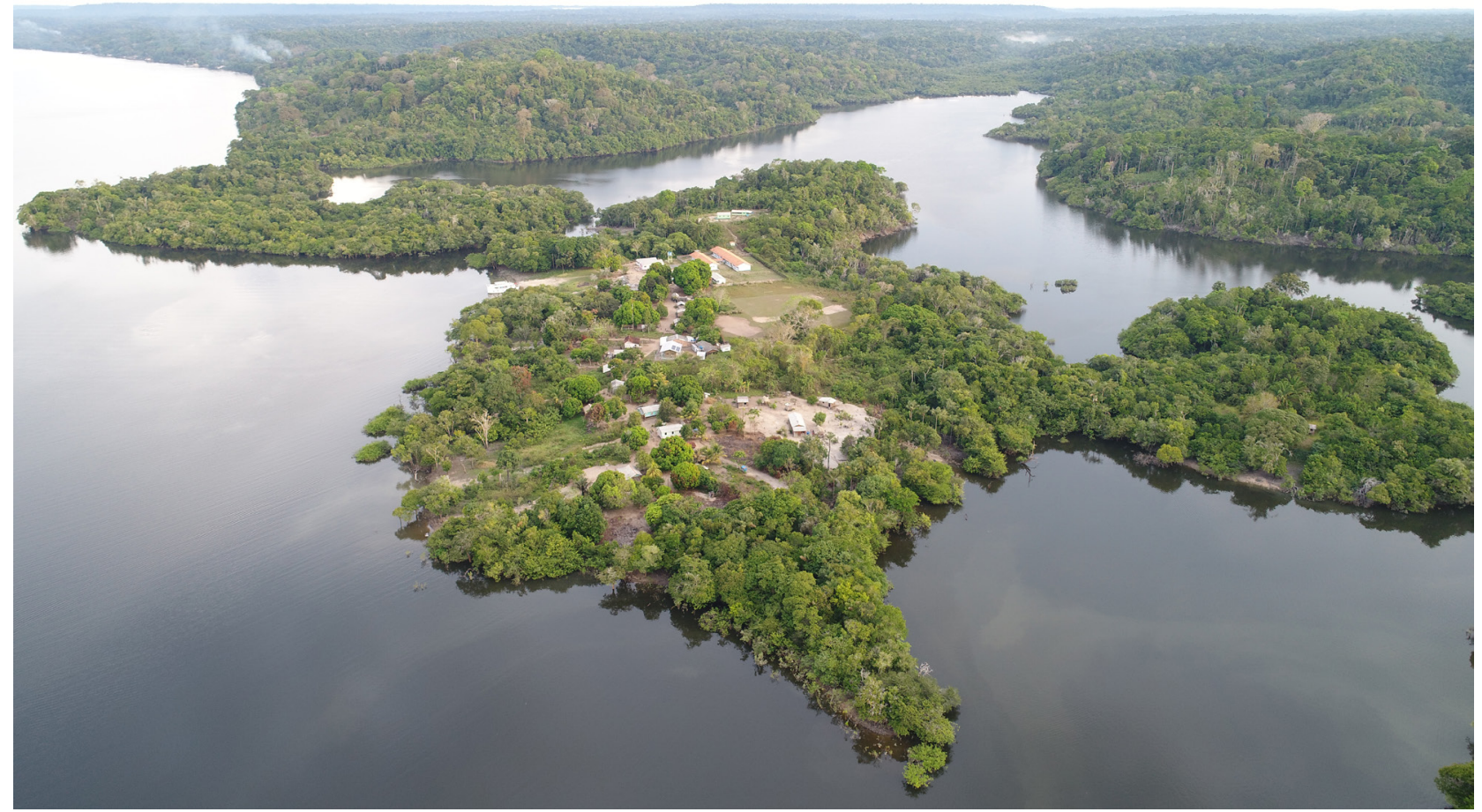

Figure S1. Aerial photography of Tapagem village, in the National Forest of Saracá-Taquera, in the Trombetas River basin, Oriximiná, state of Pará, Brazil. Crop-field and shrub-fallow plots for experimental plantings of Bertholletia excelsa were established in the surroundings of this village (see Figure 1).

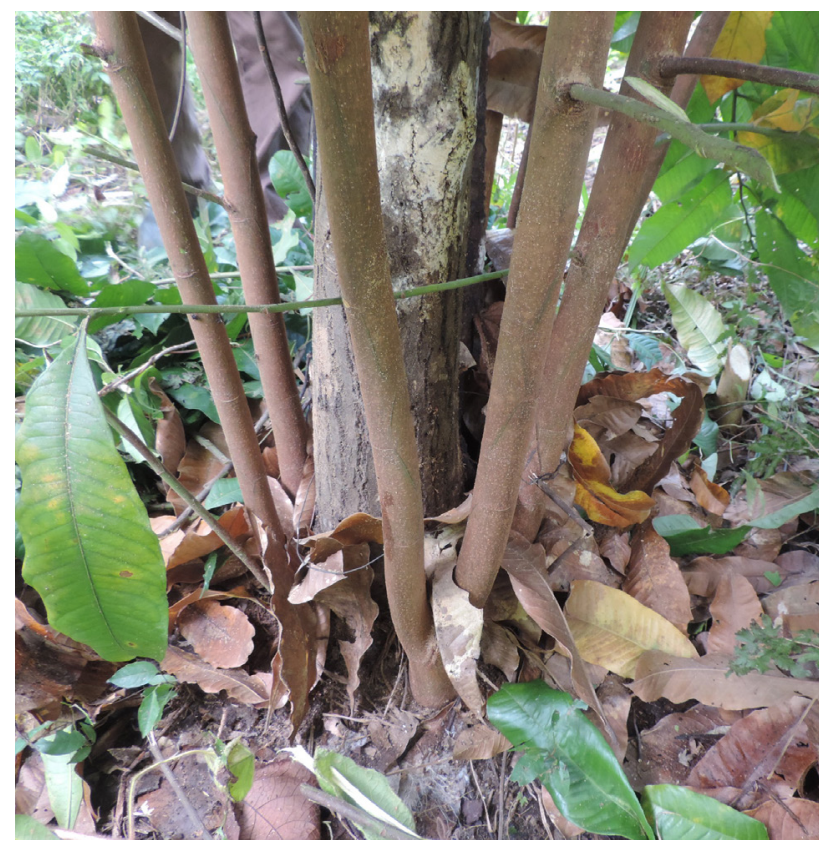

Figure S2. Resprouting of more than one new stem of a plant of Bertholletia excelsa after fire disturbance in an experimental planting in crop field.

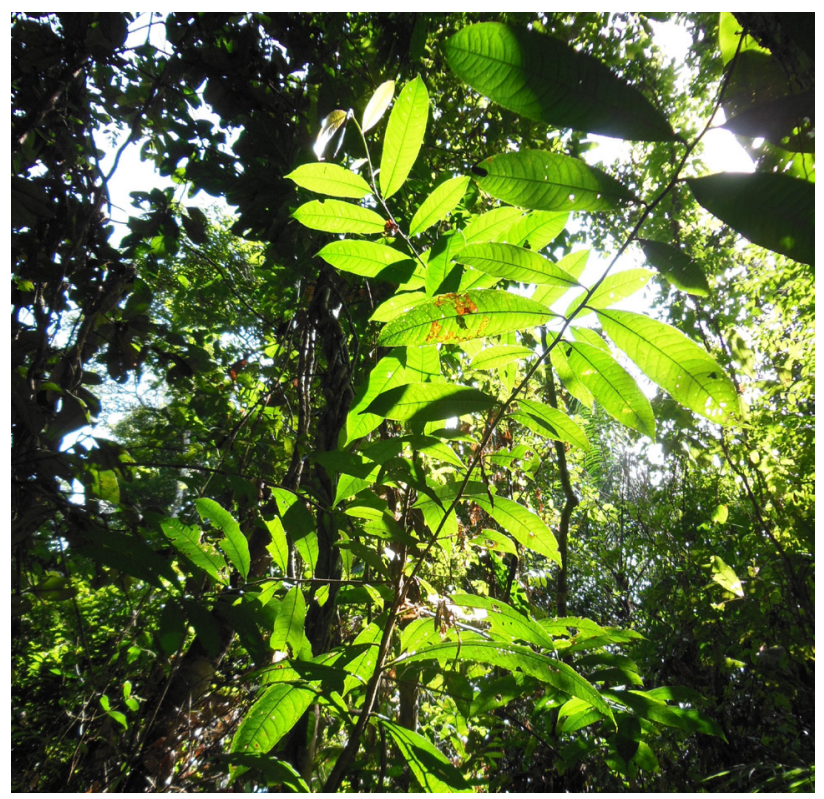

Figure S3. Bertholletia excelsa sapling in an experimental plantation within Brazil-nut forest at ten years since planting. The plantations in Brazil-nut forest were located at approximately $3 \mathrm{~km}$ from Tapagem village (Figure S1) in the National Forest of Saracá-Taquera, in the Trombetas River basin, Oriximiná, state of Pará, Brazil (see Figure 1). 
ACTA

AMAZONICA

SCOLES \& GRIBEL. Ten-year growth and survival of Brazil-nut trees

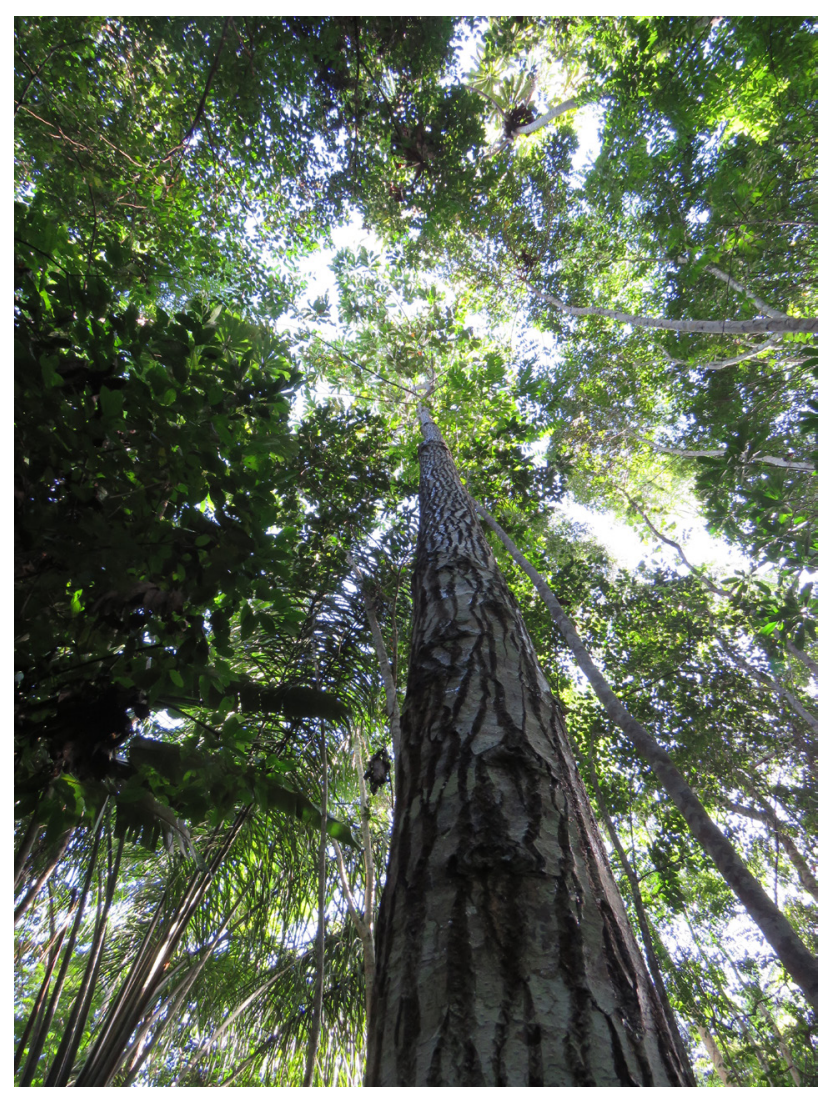

Figure S4. Young tree of Bertholletia excelsa in an experimental plantation in a crop field at ten years after planting in the National Forest of Saracá-Taquera, in the Trombetas River basin, Oriximiná, state of Pará, Brazil (Figure 1; Figure S1).

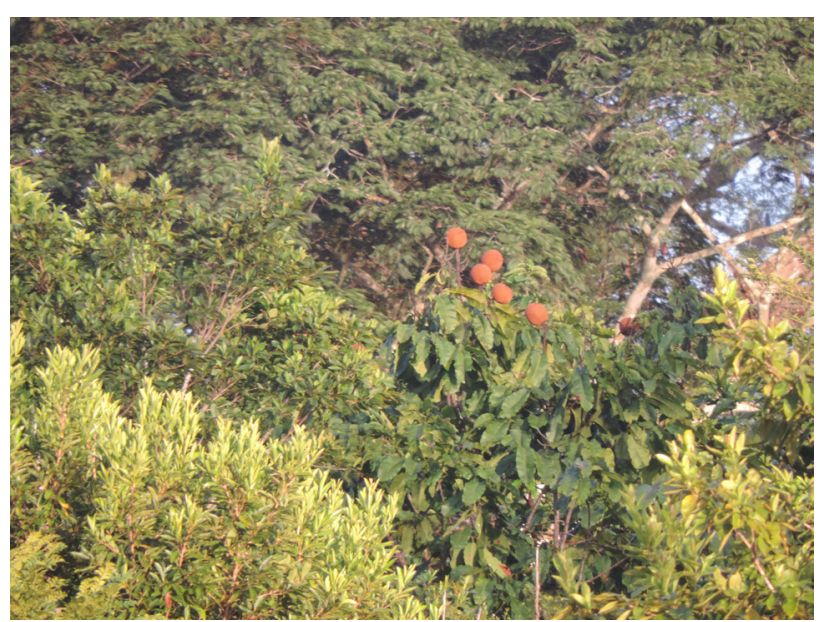

Figure S5. Fruit production in a young tree of Brazil-nut tree, Bertholletia excelsa in an experimental plantation in a crop field at ten years old after planting in the National Forest of Saracá-Taquera, in the Trombetas River basin, Oriximiná, state of Pará, Brazil (Figure 1; Figure S1). 